\title{
COMPOSITION OF LECTIN RECEPTORS IN SEROUS AND MUCINOUS OVARIAN CYSTADENOMAS
}

\section{O.M. NOSENKO \\ MD, professor at the Obstetrics and Gynecology Department № 1, 0desa National Medical University \\ ORCID: 0000-0002-7089-2476 \\ V.G. DUBININA \\ MD, professor, head of the Oncology Department with a Course of Radiation Diagnostics, Therapy and Radiation Medicine, Odesa State Medical University \\ ORCID: 0000-0002-8405-4457}

\section{M.A. LYSENKO}

postgraduate student of the Obstetrics and Gynecology Department № 1, Odesa National Medical University

ORCID: 0000-0002-5018-7921

\section{Contacts:}

Olena M. Nosenko

Obstetrics and Gynecology

Department № 1, 0desa National

Medical University

65080, 0desa, Cosmonauts street, 11b

UC "Maternity Hospital N 7"

tel.: +38 (048) 7668601

e-mail:nosenko.olena@gmail.com

\section{INTRODUCTION}

Ovarian tumors take 2 nd place among all genital formations and the 2-3rd place in the structure of emergency gynecological pathology. Over the past two decades the frequency of their occurrence among of gynecological patients increased from $6-11 \%$ to $19-25 \%$. $75-87 \%$ of all ovarian tumors are benign [1]. The most common group of benign cystic ovarian tumors in women of all ages are cystic epithelial tumors, which make up about a third of ovarian tumors and half of its his benign formations. Histogenesis of true benign ovarian tumors, despite the many years of studying history, remains unexplored [1].

\section{ANALYSIS OF PUBLISHED DATA AND FORMULATION OF RESEARCH TASK}

The growth of tumor proliferative activity is accompanied by increased amounts of lectins receptors in cells [2]. Lectins are proteins of non-immune origin who own common property to bind carbohydrates and carbohydrate determinants biopolymers strictly defined structure intact their covalent structure, and in some cases -with some subpopulations consisting unrecognized by other grounds morpho- and hystogenetic features cellular elements $[3,4]$.

The structure of the tumor antigens are carbon structures of membrane glycoproteins, glycolipids and polysaccharides. Glycoproteins are 80\% proteins located on the cell surface and in the extracellular environment. They participate in the growth and adhesion of cells, control of immune responses, regulation of proteins transport and signaling pathways such as Notch, Wnt, transforming growth factor $\beta$ and other [5-7].

It was established that the oncogenesis changes the structure of membrane glycoconjugates as well cancer as immune cells, and it was marked the advancing variability of glycoconjugates in tumor cells These changes are associated with violation of specific glycosyltransferases synthesis [8]. Glycans changes are not necessarily a consequence of mutations and deletions at the DNA level of corresponding glycosyltransferases, but rather it may be caused by epigenetic modifications of DNA such as hyperor hipomethylation that regulate the expression of the variable genes $[9,10]$.

Everything listed above is the basis for the use of labeled lectins to study changes in cell membrane and secretory glycoconjugates structures during tumor growth.

The aim of the study was to determine the receptor of lectins and their carbohydrate determinants in serous and mucinous cystadenomas.

\section{MATERIALS AND METHODS}

120 operated patients of reproductive age were under observation. Group $C$ was 60 women with ovarian serous cystadenomas; Group M - 60 women with mucinous cystadenomas. The diagnosis was confirmed histologically.

Operating materials were fixed in 10\% neutral formalin solution ( $\mathrm{pH}$ 7.4). To detect glycoconjugates it was using peroxidase labeled lectins set of different carbohydrate specificity. Lectins were made in the laboratory "Lectynotest" from raw of Carpathian region (Lviv, Ukraine): LCA - seed lectin Lentil (Lens culinaris lectin; specificity - aMan > aGlc); WGA - wheat germs (Triticum wulgare agglutinin; NAcDGlc $>$ NAcNeu); LAL - crust of golden rain (Laburnum anagyroides lectin; aL-Fuc); SBA - soybean seeds (Soy-bean agglutinin; NAcDGal); PNA - peanuts seeds (Peanuts agglutinin; $\beta$-D-Gal-H $\rightarrow$ 3, DGal NAcDGal); HPA - snail (Helix pomatia agglutinin; aNAcDGal, NAcGlc); SNA - bark elderberry (Sambucus nigra agglutinin; Neu5AC/2 $\rightarrow 6 \mathrm{Gal}$ ); VAL - mistletoe (Viscum album lectin; DGal).

Sections 4-5 microns thick were studied using light microscope Olympus BX-40. Digital photography apparatus carried C200 ZOOM Olympus DpSoft. Statistical analysis of the data was performed using Microsoft Excel.

\section{RESULTS AND DISCUSSION}

The average age of women with serous cystadenomas was $30.10 \pm 0.51$ years, with mucinous cystadenomas $-30.17 \pm 0.47$ and didn't significantly differ between groups. The average diameter of serous cystadenomas equal to $9.06 \pm 0.60 \mathrm{~cm}$, mucinous $11.97 \pm 0.81 \mathrm{~cm}$.

Characteristic of serous and mucinous cystadenomas was the accumulation of lectins receptors WGA, PNA and SBA in their cells (Fig. 1-3).

Peanut lectin (PNA) interacts with the T-antigen and related structures with terminal molecule of $\mathrm{D}$-galactose to $\mathrm{N}$-linked acethylglucosamine and ASIA-GM1 tetracarbohydrate. Wheat germ lectin (WGA) connects dicarbohydrate neuraminic-N-acidacethylglucosamine (NeuAc-NAcGlc-R) and soybean lectin (SBA) - a-methyl- $N$-acetyl-B-galactosamine (GalNAc-a) and oligosaccharide residues with terminal molecules GalNAc-a. Lectins PNA, WGA and SBA have cytotoxic effects and inhibit cell adhesion [11]. Among receptor glycoconjugates in the epithelium of some serous cystadenomas largest content was receptors PNA and WGA. Papillary serous cystadenomas differed moderate accumulation in the epithelium of papillae throughout the cytoplasm lectin receptors SBA, VAL (Fig. 4) and WGA (Fig. 1B). 

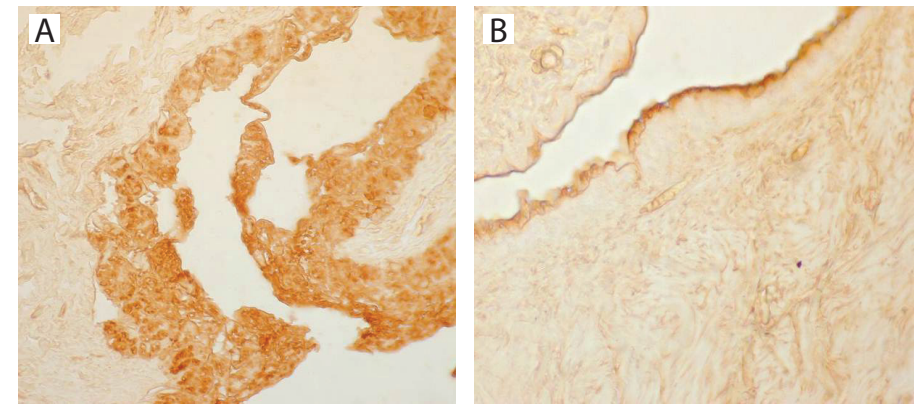

FIGURE 1. UNEVEN, MODERATE TO HIGH ACCUMULATION

of wheat lectin receptors (WGA) in epithelium of mucinous (A) and serous (B) cystadenomas. Processing of cuts by wheat lectin with peroxidase. Magnification $\times 400$.

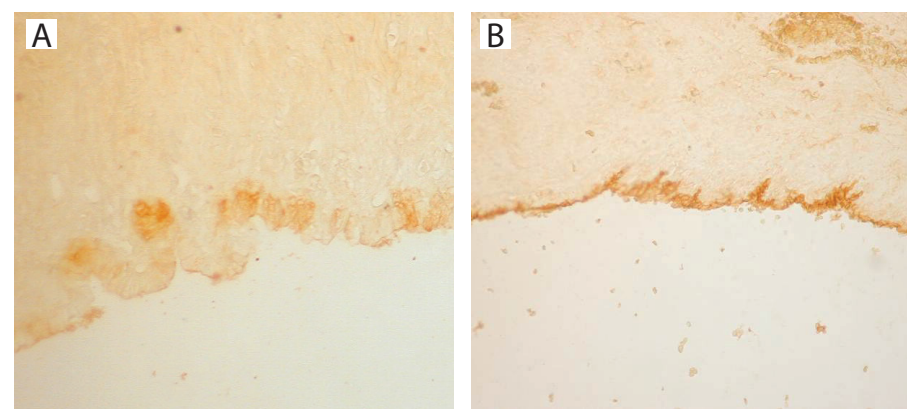

FIGURE 2. UNEVEN, FROM LOW TO HIGH ACCUMULATION

of peanut lectin receptors (PNA) in epithelium of mucinous (A, magnification $\times 400)$ and serous $(B$, magnification $\times 200)$ cystadenomas. Processing of cuts by peanut lectin with peroxidase.

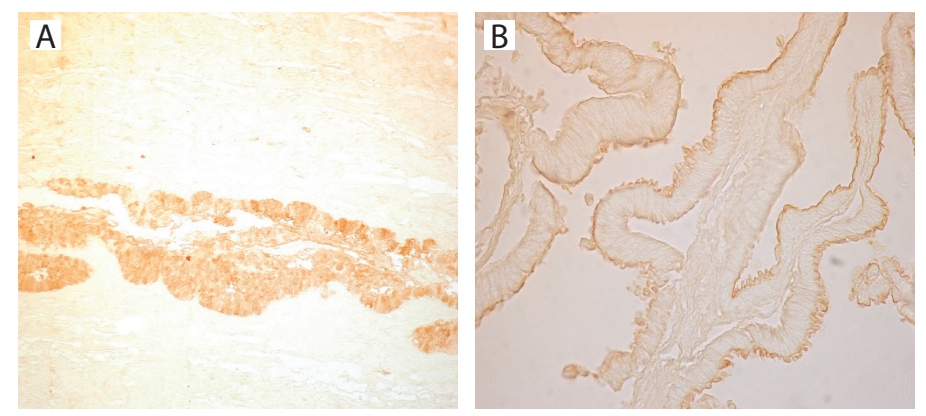

FIGURE 3. UNEVEN MODERATE ACCUMULATION

of soybean lectin receptors (SBA) in the cytoplasm of epithelial cells of mucinous

cystadenoma (A, magnification $\times 100)$ and apical part of epithelial cells papillary serous

cystadenoma (B, magnification $\times 400)$. Processing of cuts by soybean lectin with peroxidase.

For mucinous cystadenomas it was typical the accumulation of glycoconjugates in epithelial lining. The most intense and uniform in mucinous cystadenomas was expression of lectin receptor SNA, binding neuraminic acid, and SBA (Fig. 5). Also, there was an intense mosaic expression of receptors PNA, WGA, LAL, LCA, HPA.

Appearance receptor PNA, SBA, HPA cells in serous and mucinous cystadenomas can explain by violation of the processes of the final glycosylation of biopolymers containing carbohydrates, namely, the lack of camouflage terminal residues of D-galactose sialic acid. These violations of final glycosylation of lectins receptors in serous and mucinous cystadenomas are manifestations of sharply reduced general ability of tumor cells to produce glycolipids and glycoproteins with fully synthesized oligosaccharides chain.

The hypersialylation of epithelial cells of serous and mucinous cystadenomas, accompanied by the accumulation of receptors WGA and SNA, shows a decline in cell differentiation. Usually in hypersialylational cells there is no accumulation of fucoconjugates. Characteristic features of mucinous cells were simultaneous presence fuco-and sialoconjugates.
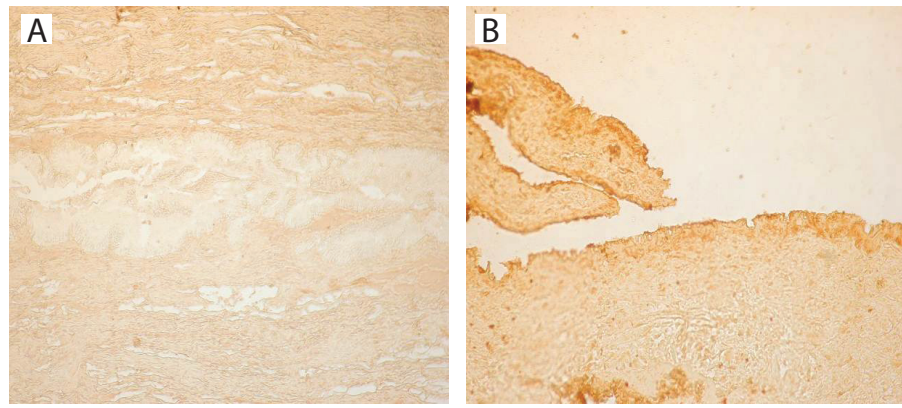

FIGURE 4. TRACKS MISTLETOE LECTIN RECEPTORS (VAL) IN EPITHELIUM OF MUCINOUS CYSTADENOMA (A) AND MODERATE ACCUMULATION IN THE EPITHELIUM OF PAPILLAE OF PAPILLARY SEROUS CYSTADENOMA (B) Processing of cuts by mistletoe lectin with peroxidase. Magnification $\times 400$.

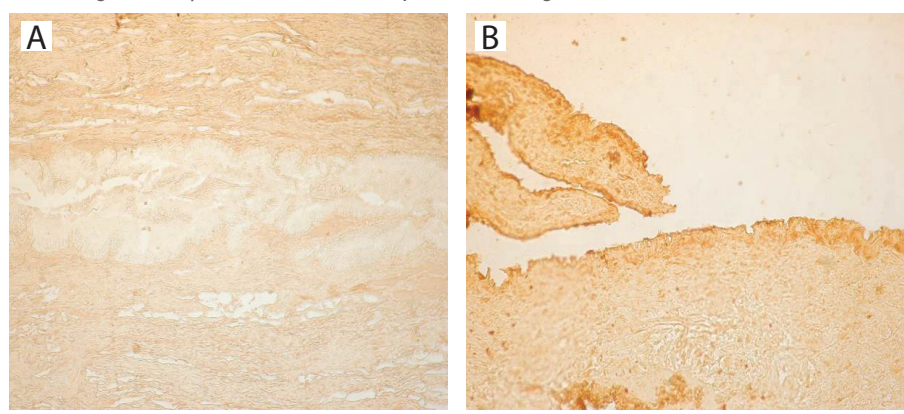

FIGURE 5. THE HIGH CONTENT OF ELDERBERRY LECTIN RECEPTORS (SNA) IN THE EPITHELIUM SMOOTH-WALLED (A) AND PAPILLARY (B) MUCINOUS CYSTADENOMAS

Processing of cuts by elderberry lectin with peroxidase. Magnification $\times 400$.

Mosaic lectin receptor expression may explain the formation of local condensable of receptors in certain areas of plasmolemma due to changes molecular spatial structure glycoconjugates plasmolemma surface of tumor cells and increasing the mobility of membrane receptors of lectins that keeping-phenomenon. The combination of the above composition and properties of surface glycoconjugates causes lack of contact inhibition of cell proliferation - the cardinal signs of tumor cells.

In cell adhesion fucolihandes of membrane glycoconjugates are also important. In the studied formations it was observed absence of the low content fucolihandes, in some mucinous cystadenomas - moderate content, indicating the presence of tumor properties of these entities. Reducing the strength of the surface glycoconjugates, synthesized by formations cells, hypersialylation of epithelial surfaces of cystadenomas leads to lower recognition by mononuclear phagocytes system, prevents elimination ofcells bytheimmunesystemand,consequently,topersistence.

Increased affinity for lectins can be caused by a decrease in the degree of intercellular communication and detection of carbohydrate determinants of cytolemma outer layer that enables penetration of lectins in the middle of the cell and settling their respective carbohydrate fragments in the cytosol. Increasing the number of receptors explains the incompleteness of the final glycosylation lectins receptors, therefore metabolism violation in tumor cells.

\section{CONCLUSION}

Changes in the molecular-spatial structure of glycoconjugates of the plasmolemma cells surfaces and increase of the mobility of membrane lectins receptors in serous and mucinous cystadenomas cause lack of contact inhibition of proliferation. Further study of lectins can contribute to the elucidation of the pathogenesis of ovarian formations, their differential diagnosis, the development of tumor markers and drugs lectins. 


\section{REFERENCES/ЛІTEPATУPA}

1. Носенко, 0.M.

Доброякісні кістозні утворення яєчників: епідеміологія,

патогенез, діагностика та відновлення репродуктивного

здоров'я: автореф. дис...... Д. мед. н. : 14.01 .01 /

0.М. Носенко. - Київ, 2008. -42 c.

Nosenko, 0.M.

Benign cystic formation of ovary: epidemiology, pathogenesis, diagnosis and recovery of reproductive health. The thesis for submitting an academic degree of doctor of medical sciences: 14.01.01. Kyiv (2008): 42 p.

2. Ященко, А.М.

Лектини як гістохімічні маркери в нормі та патології: автореф. дис. ... д. мед. н. : 14.03.09/ А.М. Ященко. - Київ, 2004. -35 C.

Yashchenko, A.M.

Lectins as histochemical markers in health and disease. The

thesis for submitting an academic degree of doctor of medical sciences: 14.03.09. Kyiv (2004): 35 p.

3. Varki, A., Cummings, R.D., Esko, J.D., Freeze, H.H., et al. Essentials of Glycobiology. 3rd edition. Cold Spring Harbor (NY) Cold Spring Harbor Laboratory Press (2015): $800 \mathrm{p}$.

4. Яковцова, И.И.

Распределение лектиновых рецепторов в эпителии серозных опухолей яичников / И.И. Яковцова // Архив клинической и экспериментальной медицины. - 1995. T. 4. № 1 - - C. 22-24.
Yakovtsova, I.I.

"Distribution of lectin receptors in the epithelium of serous ovarian tumors." Archive for Clinical and Experimental Medicine 4.1 (1995): 22-24.

5. Thiel, S., Kolev, M., Degn, S., Steffensen, R. et al.

"Polymorphisms in mannan-binding lectin (MBL)-associated serine protease 2 affect stability, binding to MBL, and enzymatic activity." J Immunol 182.5 (2009): 2939-47.

DOI: $10.4049 /$ jimmunol.0802053

6. Allam, H., Aoki, K., Benigno, B.B., McDonald, J.F., et al.

"Glycomic analysis of membrane glycoproteins with bisecting

glycosylation from ovarian cancer tissues reveals novel structures and functions." J Proteome Res 14.1 (2015): 434-46. DOl: $10.1021 / p r 501174 p$

7. Takahashi, M., Kuroki, Y., Ohtsubo, K., Taniguchi, N. "Core fucose and bisecting GlcNAc, the direct modifiers of the N-glycan core: their functions and target proteins." Carbohydr Res 344.12 (2009):1387-90.

DOl: $10.1016 /$ j.carres.2009.04.031

8. Гнедкова, И.А.

Лектинсвязывающие и туморогенные свойства клеток глиомы С / И.А. Гнедкова, Н.И. Лисяный, Д.Н. Станецкая и др. // Онкология. - 2015. - Т. 17, № 1. - С.4-11.

Gnedkova, I.A., Lisyanyi, N.I., Stanetskaya, D.N., et al.

"Binding of lectins and tumorigenic properties of glioma cells

C6." Oncology 17.1 (2015): 4-11.
9. Anugraham, M., Jacob, F., Nixdorf, S., et al. "Specific glycosylation of membrane proteins in epithelial ovarian cancer cell lines: glycan structures reflect gene expression and DNA methylation status." Mol Cell Proteomics 13.9 (2014):2213-32.

DOl: 10.1074/mcp.M113.037085

10. Rodriguez-Paredes, M., Esteller, M. "Cancer epigenetics reaches mainstream oncology." Nat Med 17 (2011):330-9.

11. Антонюк, В.0.

Пектини та їх сировинні джерела / В.0. Антонюк. - Львів: Кварт. $-2005 .-554$ c

Antoniuk, V.0.

Lectins and their sources of raw materials. Lviv. Quart (2005): $554 \mathrm{p}$.

\section{РЕЦЕПТОРНИЙ СКЛАД ЛЕКТИНІВ В СЕРОЗНИХ ТА МУЦИНОЗНИХ ЦИСТАДЕНОМАХ ЯЕЧНИКІВ}

О.М. Носенко, д. мед. н., професор кафедри акушерства та гінекології № 1 Одеського НМУ

В.Г. Дубініна, д. мед. н., професор, зав. кафедрою онкології з курсом променевої діагностики, терапії та радіаційної медицини Одеського Нму

М.А. Лисенко, аспірант кафедри акушерства та гінекології № 10 деського НМУ

Найпоширенішою групою кістозних доброякісних пухлин яєчників у жінок різного віку є епітеліальні пухлини (цистаденоми), які складають приблизно третину від загальної кількості пухлин яєчника і половину від його доброякісних утворень.

Зростання проліферативної активності пухлин супроводжується підвищенням кількості рецепторів лектинів у клітинах. Лектини - це білки неімунного походження, що володіють загальною властивістю зв'язувати вуглеводи і вуглеводні детермінанти біополімерів чітко визначеної структури без змін їх ковалентної будови. Встановлено, що при онкогенезі змінюється структура мембранних глікокон'югатів як пухлинних, так і імунокомпетентних клітин, причому відзначають випереджальну мінливість глікокон'югатів на пухлинних клітинах. Це є підставою для застосування мічених лектинів у вивченні змін клітинних мембран і структури секреторних глікокон'югатів при пухлинному рості.

Метою дослідження стало визначення рецепторного складу лектинів в серозних та муцинозних цистаденомах.

Досліджено операційний матеріал від 60 жінок, прооперованих з приводу серозних цистаденом яєчників, і від 60 осіб - з приводу муцинозних цистаденом. Для виявлення глікокон'югатів використовували набір мічених пероксидазою лектинів різної вуглеводної специфічності.

Характерним для серозних і муцинозних цистаденом було накопичення в їхніх клітинах рецепторів лектинів зав'язків пшениці (WGA), насіння арахісу (PNA) та насіння сої (SBA). Папілярні серозні цистаденоми відрізнялися помірним накопиченням в епітелії сосочків по всій цитоплазмі рецепторів лектинів насіння сої (SBA), омели (VAL) і зав'язків пшениці (WGA). Найбільш інтенсивною і рівномірною в муцинозних цистаденомах була експресія рецепторів лектинів кори бузини чорної (SNA) і насіння сої (SBA).

Автори роблять висновок про те, що зміни молекулярно-просторової структури глікокон'югатів поверхонь плазмолеми клітин і зростання рухливості мембранних рецепторів лектинів при серозних та муцинозних цистаденомах обумовлюють відсутність контактного гальмування проліферації. На їхню думку, подальше вивчення лектинів сприятиме з'ясуванню патогенезу оваріальних утворень, їхній диференційній діагностиці, розробці онкомаркерів та препаратів лектинів.

Ключові слова: серозні цистаденоми, муцинозні цистаденоми, лектини, глікокон'югати, проліферація.

\section{COMPOSITION OF LECTIN RECEPTORS IN SEROUS AND MUCINOUS OVARIAN CYSTADENOMAS}

0.M. Nosenko, MD, professor at the Obstetrics and Gynecology Department № 1, 0desa National Medical University

V.G. Dubinina, MD, professor, head of the Oncology Department with a Course of Radiation Diagnostics, Therapy and Radiation Medicine, Odesa National Medical University

M.A. Lysenko, postgraduate student of the Obstetrics and Gynecology Department № 1, 0desa National Medical University

The most common group of benign cystic ovarian tumors in women of all ages are epithelial tumors (cystadenomas) that make up about a third of ovarian tumors and half of benign lesions.

The growth of tumor proliferative activity accompanied by increased number of lectins receptors in cells. Lectins are non-immune origin proteins that have a common property of binding carbohydrates and carbohydrate determinants of biopolymers strictly defined structure and intact their covalent structure. It was established that oncogenesis changes of the structure of glycoconjugates membrane as cancer and immune cells, and mark faster than glycoconjugates variability in tumor cells. This is the basis for the use of labeled lectins to study changes in cell membrane and secretory structures of glycoconjugates during tumor growth.

The aim of the study was to determine the composition of the receptors in serous and mucinous cystadenomas.

Operating material was studied from 60 women operated on for ovarian serous cystadenomas, and from 60 patients - on for ovarian mucinous cystadenomas. To identify the set of glycoconjugates it were used peroxidaselabeled lectins with different carbohydrate specificity.

Characteristic of serous and mucinous cystadenomas was the accumulation of lectins receptors in their cells of wheat germs (WGA), groundnut seed (PNA) and soybean seeds (SBA). Papillary serous cystadenomas differed moderate accumulation in the epithelium papillae throughout the cytoplasm lectins receptors of SBA, mistletoe (VAL) and WGA. The most intense and uniform expression in mucinous cystadenomas was one of lectin receptors of bark elderberry (SNA) and SBA.

The authors conclude that changes in the molecular-spatial structure of glycoconjugates of the plasmolemma cells surfaces and increase of the mobility of membrane lectins receptors in serous and mucinous cystadenomas cause lack of contact inhibition of proliferation. In their opinion, further study of lectins can contribute to the elucidation of the pathogenesis of ovarian formations, their differential diagnosis, the development of tumor markers and drugs lectins.

Keywords: serous cystadenoma, mucinous cystadenoma, lectins, glycoconjugates, proliferation.

\section{СОСТАВ РЕЦЕПТОРОВ ЛЕКТИНОВ В СЕРОЗНЫХ И МУЦИНОЗНЫХ ЦИСТАДЕНОМАХ ЯИЧНИКОВ}

Е.Н. Носенко, д. мед. н., профессор кафедры акушерства и гинекологии № 10 десского Нму

В.Г. Дубинина, д. мед. Н., профессор, зав. кафедрой онкологии с курсом лучевой диагностики, терапии и радиационной медицины Одесского Нму

М.А. Лысенко, аспирант кафедры акушерства и гинекологии № 10 десского НМУ

Наиболее распространенной группой кистозных доброкачественных опухолей яичников у женщин разного возраста являются эпителиальные опухоли (цистаденомы), которые составляют примерно треть от общего количества опухолей яичника и половину от его доброкачественных образований.

Рост пролиферативной активности опухолей сопровождается повышением количества рецепторов лектинов в клетках. Лектины - это белки неиммунного происхождения, обладающие общим свойством связывать углеводы и углеводородные детерминанты биополимеров строго определенной структуры без изменений их ковалентного строения. Установлено, что при онкогенезе меняется структура мембранных гликоконъюгатов как опухолевых, так и иммунокомпетентных клеток, причем отмечают опережающую изменчивость гликоконъюгатов на опухолевых клетках. Это является основанием для применения меченых лектинов в изучении изменений клеточных мембран и структуры секреторных гликоконъюгатов при опухолевом росте.

Целью исследования стало определение рецепторного состава лектинов в серозныхи муцинозныхцистаденомах.

Исследован операционный материал от 60 женщин, прооперированных по поводу серозных цистаденом яичников, и от 60 - по поводу муцинозных цистаденом. Для выявления гликоконъюгатов использовали набор меченых пероксидазой лектинов различной углеводной специфичности.

Характерным для серозных и муцинозных цистаденом было накопление в их клетках рецепторов лектинов завязей пшеницы (WGA), семян арахиса (PNA) и семян сои (SBA). Папиллярные серозные цистаденомы отличались умеренным накоплением в эпителии сосочков на протяжении всей цитоплазмы рецепторов лектинов семян сои (SBA), омелы (VAL) и завязей пшеницы (WGA). Наиболее интенсивной и равномерной в муцинозных цистаденомах была экспрессия рецепторов лектинов коры бузины черной (SNA) и семян сои (SBA).

Авторы делают вывод о том, что изменения молекулярно-пространственной структуры гликоконъюгатов поверхностей плазмолеммы клеток и рост подвижности мембранных рецепторов лектинов при серозных и муцинозных цистаденомах обусловливают отсутствие контактного торможения пролиферации. По их мнению, дальнейшее изучение лектинов может способствовать выяснению патогенеза овариальных образований, их дифференциальной диагностике, разработке онкомаркеров и препаратов лектинов.

Ключевые слова: серозные цистаденомы, муцинозные цистаденомы, лектины, гликоконъюгаты, пролиферация. 